\title{
Regional development and engineering education: an analysis of Brazil's micro-regional scenario
}

\author{
Vitor Mendes Caldana ${ }^{a *}$, Marcia Terra da Silva ${ }^{\mathrm{b}}$ \\ alnstituto Federal de São Paulo, Sorocaba, SP, Brazil \\ bUniversidade Paulista São Paulo, São Paulo, SP, Brazil \\ *vitor.caldana@ifsp.edu.br
}

\begin{abstract}
Regional development is fundamental to equally develop countries. This paper focus on the micro-regional aspect of engineering education and its spillovers to understand the current impact in macro regional Human Development Indexes of Education (HDI_E) and Revenue (HDI_R). A complete analysis of official government data in all micro-regions, the number of Engineering institutions, total graduates and total enabled engineers is cross-referenced with bibliographical review. This paper reaches the conclusion that not only the scenario is challenging but changes are needed to reverse the unequal situation found in the country as the presence of Engineering Universities is directly related to better results in Revenue (HDI_R) and General Education (HDI_E).
\end{abstract}

Keywords

Regional development. Micro-region. Engineering education.

How to cite this article: Caldana, V. M., \& Silva, M. T. (2017). Regional development and engineering education: an analysis of Brazil's micro-regional scenario. Production, 27(spe), e20162250. http://dx.doi.org/10.1590/0103-6513.225016

\section{Introduction}

It has been consistent over the years, as displayed by the Organization for Economic Co-operation and Development (OECD) since its foundation in 1961 and, more specifically the Going for Growth reports since 2005, that the amount of Human Resources in Science and Technology (HRST) is directly linked to a country's Gross Domestic Product (GDP). Considering the importance of evolving its national economy, several Brazil researches have considered this particular theme, especially in regard to the lack of engineers. Examples of this work can be seen in Nascimento (2011), Salerno et al. (2014), Lins et al. (2014), Maciente \& Araújo (2011), Nascimento et al. (2010) among others. Special attention is needed for the information provided by Maciente \& Araújo (2011) that only 38\% of engineers remain on their main activity, with the rest applied elsewhere. The researchers do not present a conclusion if the issue is curriculum, the quality of the graduate, market demands or other factors.

The studies above found no evidence of a structural lack of engineers - in which a country is unable to graduate enough engineers to supply the market demands - as the output of universities and market demands analyzed seems to be met in most criteria. However, these studies are mainly based on the economic output and market requirements and the approach given is almost entirely focused on economic activity, the generation of engineering workforce and the ability of employment or repositioning of professionals. The typical spillovers and capacities of engineers to enhance production and boost economic regional development by technological innovation and entrepreneurship, the presence of universities and their spillovers, and the quality of degrees are not considered (even though some studies do mention the variables).

In this sense, lins et al. (2014) displays a country-by-country correlation between HRST presence and GDP per capita. The author's present data that would indicate an estimated value of GDP for HRST available 
in the country. The data shows the capacity of some countries to leverage their GDP per capita to be above the correlation line (such as Japan, USA and Norway) and the inability of others to take advantage of the HRST resources (such as Brazil, Turkey and Poland). This clearly indicates that the amount of HRST per se is insufficient to understand the countries global GDP and other factors must be taken into consideration, such as regional presence and quality of degrees. Nascimento (2011) concludes that there is not a structural shortage of engineers in Brazil considering the countries global economic and market perspectives, the regional factor was not properly considered.

The similarity between Brazil's Macro Regions GDP participation and the distribution of high quality Engineering High Education Institution (HEl's) in that same region is displayed in Figure 1. The importance of a micro-regional analysis and its development, especially in a country as vast as Brazil $\left(8,516,000 \mathrm{~km}^{2}\right)$, is fundamental to allow the regions to balance their results and to equally develop the country. However, it is important to notice that in no way this study considers a cause-effect type of scenario as the factors of development are vastly complex.

Local development is covered in length with authors such as Quandt (1997), Costa (2010) and Oliveira (2011), in which they signal to the importance of the local factor in Brazil, while others such as Lozano et al. (2014), Stephens et al. (2008) and Zilahy \& Huisingh (2009) pointing out the roles that academia can have in implementing economic development practices and techniques. Devine-Wright et al. (2001) point to the necessity of accounting social capital at the local scenario level, as different cultures will have specific ways to solve problems and present solutions. Kakiuthi et al. (2014) show new possibilities for improving science education to better prepare the students going into universities in the hope that the quality of the HRST that enter, and thus graduate, will be increased. All of the authors contribute to the conclusion that is impossible to stablish a simple cause-effect scenario as the analysis of development and graduation are to complex and similar to a symbiotic relationship.

Based on the idea to be developed on this paper of a more microscopic view, the work of Lendel (2010) presents the concept of "University Products". It is proposed that depending on regional needs, mission statement and policies each university can provide up to seven different products to the region such as: 1) education, 2) applied research, 3) cultural products, 4) trained labor, 5) technology diffusion, 6) new knowledge creation and 7) new products and industries. Even considering the relevance of the university and its influence at a higher level (state or even national), Drucker (2016) points to the fact that the regional spillover is present. Per this author, positive local impacts can still be noticed up to $97 \mathrm{~km}$ (60 miles) and, as such, this spillover effect is particularly important in research universities that produce technology and innovation. The conclusion by Drucker (2016) adds to the idea that the regional presence and placement of Engineering HEl's is important and also corroborates with the findings of Figure 1.

With the products mentioned by Lendel (2010) each micro-region can establish the seven elements of technology-based development (Skilled Workforce, Intellectual Infrastructure, Knowledge Spillover, Capital, Physical Infrastructure, Entrepreneurial Culture and Quality of Life) and it is possible to assess the impact the university can have on its local community. This is not a simple task as most of the products are bundled and the effects can't be seen separately so more complex models need to be developed.

Based on the literature background, this research's objective is to explore HEl's allocation and the population affected by them on each (and all) micro-regions in Brazil and to identify how key aspects of the Human Development Index (HDI) - Education and Revenue - are better or worse compared to the macro-region. This research will also add to the discussion of the OECD about the relationship between HRST professionals and

REGIONAL \% OF GDP

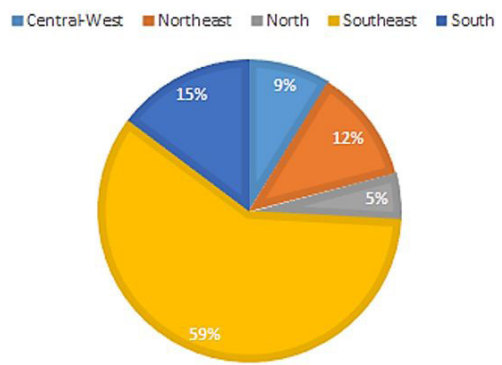

\% OF HEI WITH GOOD PERFORMANCE

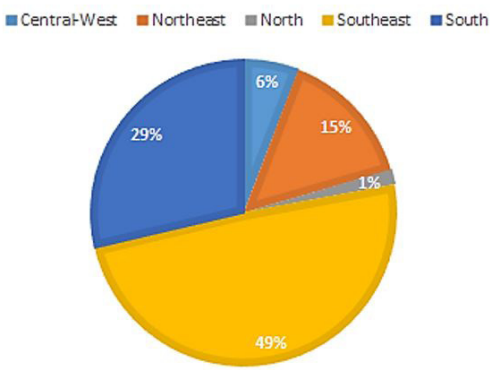

Figure 1. Regional GDP and Regional High Performance HEl's. Source: (IBGE, 2014; INEP, 2015). 
GDP and explore the possibility of a regional lack of engineers in Brazil. This work can orient key actors in universities and government policy makers to place or develop new public and private institutions as well as manage the set of mission statements to produce the correct set of products for an increase in HDI and, in a long-term scenario, a more balanced output of Macro-regional GDP with a better and more equal development of the nation's regions.

\section{Methodology}

Studies concerned about the quality and quantity of graduates concluding their graduation courses in Brazil focus primarily on the National Exam of Student Performance (ENADE) grade, as seen in Barbosa \& Santos (2011), Andrade (2011), Pederneiras et al. (2011) among others. The result from ENADE evaluates graduation students in a grade from 1 to 5 , with 5 being the highest score. Good performance evaluation is considered on grades 4 and 5. ENADE takes into consideration both specific and general performance. The general graduation curriculum represents $25 \%$ of the total grade and the specific represents $75 \%$. After calculating the average grade and standard deviation for each particular $\mathrm{HEl}$, the method than calculates the average and standard deviation of all HEl's in that specific area that took the test to standardize the grade in all Brazil (INEP, 2011).

To better understand the impacts of HEl's in their micro-region, a more complete method of evaluation is needed as ENADE focuses only on the graduate. As demonstrated early there are several products that university can provide and other spillovers that are not only the number of graduates and the quality of them. To achieve this purpose this study selected the Preliminary Course Concept - CPC (Conceito Preliminar de Curso). The CPC grade also aggregates other variables such as professors and institute facilities. The calculation criteria and the detailed document is available from the National Institute of Studies and Research - INEP (Instituto Nacional de Estudos e Pesquisas) (INEP, 2016). The CPC formula from 2011 used the following indexes:

$$
C P C_{j}=\left(0.35 * N I D D_{j}\right)+\left(0.20 * N C_{j}\right)+\left(0.15 * N D_{j}\right)+\left(0.075 * N M_{j}\right)+\left(0.075 * N R_{j}\right)+\left(0.075 * N O_{j}\right)+\left(0.05 * N F_{j}\right)+\left(0.025 * N A_{j}\right)
$$

Where:

- $\mathrm{CPC}_{\mathrm{j}}$ is the calculated value of the index for each HEl

- $\mathrm{NIDD}_{\mathrm{j}}$ is the index that reflects the "advance" in knowledge from the students (it measures the difference between the average of ENDAE scores of freshmen and graduates at the institution)

- $N C_{j}$ is the ENADE score

- $\mathrm{ND}_{\mathrm{j}}$ is the proportion of teachers with PhD's in the HEl

- $\mathrm{NM}_{\mathrm{j}}$ is the proportion of teachers with Masters in the HEl

- $\mathrm{NR}_{\mathrm{j}}$ is the work regime of the teachers (better grades are given to exclusive professionals)

- $\mathrm{NO}_{\mathrm{j}}$ is the grade from the Pedagogical assessment

- $\mathrm{NF}_{\mathrm{j}}$ is the facilities grade (laboratories, classrooms, etc.)

- $\mathrm{NA}_{\mathrm{j}}$ is the grade from the opportunities given by the HEl for continuous study

Since results from Engineering Schools are taken every three years, and to get data as close as possible to the official data regarding the cities that is available from 2010, this study selected the CPC results from 2011 instead of the results from 2014 or 2008.

This study creates a cross-reference guide between all of the 5,565 cities present in the 2010 census categorizing them by micro-region (IBGE, 2012; PNUD et al., 2013). After that the 1,169 Engineering HEl's that took the ENADE exam were sorted in their respective cities and divided into CPC categories (INEP, 2015). To establish a mean to consolidate the universities 5 categories were created.

- $\mathrm{CPC} 1$ has HEl's with grades from 0.01 to 1

- $\mathrm{CPC} 2$ has HEl's with grades from 1.01 to 2

- $\mathrm{CPC} 3$ has HEl's with grades from 2.01 to 3

- CPC4 has HEl's with grades from 3.01 to 4

- $\mathrm{CPC} 5$ has HEl's with grades from 4.01 to 5 
With this division and the official data provided by ENADE it was possible to establishing the number of HEl's, the CPC score and also the number of graduates that took the ENADE exam by city. This allowed to determine the distribution of Engineering Education HEl's in Brazil and also the possible impact of Engineering HEl's as a complete institution and not only as "factory" of graduates. The proposition is that the data reveals that the presence of HEl's, especially high-quality CPC grades (CPC4 and CPC5), are more significant in the micro-regions of the South and Southeast as they are the macro regions with the highest GDP participation. This suggests a relation between the presence of HEl's and regional GDP, as proven by Figure 1 and OCDE reports.

To assess the impact of the HEl's as a whole, this study selected the Human Development Index (HDI) index, as it is largely utilized in comparison between countries and has no direct impact from higher education (the education portion uses as far as high school level), being able to represent the effects on a broad spectrum and on long-term influences. The HDI index is calculated as a geometric average between three components: Education, Income and life Expectancy.

The HDI_L (Life expectancy) portion of the HDI index was not used in this study as the establishment of this index depends on tables and assessments on health care that are not available for the micro-regions. Attempts conducted to achieve this index from the cities within the micro-regions (provided by official data) using different calculation methods such as normal average, population weighted average and geometric average all presented a margin of error that led to the conclusion that the index should be discarded. Regardless, even though a better education can lead to a better lifestyle and most likely a better life expectancy, this is not the focus of this paper and the lncome increase and the Educational factor that can in part justify these enhancements are considered.

After the cities were divided into their respective micro-regions, for each micro-region the HDI_Education (Formula 2) and HDI_Income (Formula 5) indexes were calculated (as only state and city indexes are provided in the official data). After the indexes are calculated a comparison between the micro-regional index and state is made to assess if the micro-region has better economic and educational standards. Also, in each micro-region the number of HEl's is sorted by CPC score with the criteria mentioned before and the presence of institutions, the quality of HEl's and output of engineers in each micro-region is determined.

HDI_Education is the Educational part of the HDl. It measures the percentage of children and teenagers in school and if they are finishing the grades at the expected age. The index is independent from HEl's as it does not contemplate any kind of high-level graduation. It verifies the number of adults (+18-year-old) that have the fundamental degree and the flow of children and teenager students between elementary and high school.

$$
\text { HDI_Education } \text { Micro Re gion }_{-}=\sqrt[3]{P_{18+} *\left(\frac{P_{5-6}+P_{11-13}+P_{15-17}+P_{18-20}}{4}\right)^{2}}
$$

Where:

- HDI_Education MicroRegion $_{\text {is }}$ the calculated value of the index for each micro-region

- $\mathrm{P}_{18+}$ is the percentage of the micro-region total population over 18 years with high school degrees

- $\mathrm{P}_{5-6}$ is the percentage of the micro-region total population between 5 and 6 years in school

- $\mathrm{P}_{11-13}$ is the percentage of the micro-region total population between 11 and 13 years in the final years of elementary school

- $\mathrm{P}_{15-17}$ is the percentage of the micro-region total population between 15 and 17 years with complete elementary school

- $\mathrm{P}_{18-20}$ is the percentage of the micro-region total population between 18 and 20 years with complete high school

As an example, the indexes of the micro-region Porto Velho, located in the state or Roraima in the North macro region are: $\mathrm{P}_{18+}=56.49 \%, \mathrm{P}_{5-6}=78.15 \%, \mathrm{P}_{11-13}=84.10 \%, \mathrm{P}_{15-17}=49.14 \%$ and $\mathrm{P}_{18-20}=38.00 \%$. The formula translates to:

$$
\text { HDI_Education } \text { PortoVelho }=\sqrt[3]{0.5649 *\left(\frac{0.7815+0.8410+0.4914+0.3800}{4}\right)^{2}}=0.603
$$

A similar calculation was made by obtaining the HDI_lncome that measures the per capita income of the region. As this information is also not available at the micro-regional level, it was necessary to obtain the total population and also total income of each city. With the total values of population and income it was then possible to calculate the per capita income of the micro-region. The function used is described below in 
Equations 3 and 4. It is important to notice that since only per capita income information is available there is a small margin of error when using the calculation method described below. To assess if this error would make the study inviable for each city the Per Capita income a HDI_lncome was calculated and compared with the official state index (assuming all cities would be a part of the same micro-region), with the error, in all cases, being less than $0.05 \%$.

$$
T I_{\text {Micro Re gion }}=\sum_{i=1}^{n}\left(C P_{i} * P C I_{i}\right)
$$

Where:

- $\mathrm{Tl}_{\text {MicroRegion }}$ is the Total Income of each region

- $\mathrm{n}$ is the total number of cities in the region

- $\mathrm{CP}_{\mathrm{i}}$ is the City Population

- $\mathrm{PCl}_{\mathrm{i}}$ is the Per Capita Income of that city

Once the total income is obtained, the per capita income of the micro-region can be determined by:

$$
R P C I=\frac{T I_{\text {Micro } \text { Re gion }}}{M R P}
$$

Where:

- $\mathrm{RPCl}$ is the per capita income of the micro-region

- MRP is the micro-region total population

After obtaining the per capita income for the micro-region it was possible to standardize it utilizing the HDl_Income formula calculation described below:

$$
\text { HDI_Income }{ }_{\text {Micro Re gion }}=\frac{\ln (\text { RPCI })-\ln (\text { MinI })}{\ln (\text { MaxI })-\ln (\text { MinI })}
$$

Where:

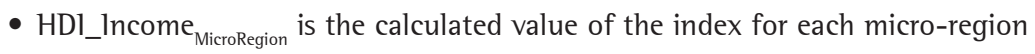

- $\mathrm{RPCl}$ is the per capita income of the micro-region

- Minl is the minimal per capita income, calculated from USD100 PPC. The value equals R\$8.00

- Maxl is the greatest per capita income, calculated from the per capita income of the $10 \%$ more rich on the wealthier state of the country. This value is $R \$ 4,033.00$.

As an example, utilizing the same micro-region Porto Velho, the RPCl calculated was $\mathrm{R} \$ 830.06$. The formula translates to:

$$
\text { HDI_Income } \text { PortoVelho }_{1}=\frac{\ln (830.06)-\ln (8.00)}{\ln (4,033.33)-\ln (8.00)}=0.746
$$

With both HDI_Education and HDI_Income micro-regional indexes calculated, a comparison with the state's official supplied indexes were obtained by Formula 6. This would show if such micro-region is better or worse than the state index, thus giving the idea of the micro-region's development factor inside each state. The comparison with state values instead of the national value was necessary to offset for the unequal development as shown in Figure 1, with the state value giving a better understanding of the micro-region compared to the area it is inserted in.

$$
\% H D I_{\text {Micro Re gon }}=\frac{H D I_{\text {Microregion }}-H D I_{\text {State }}}{H D I_{\text {State }}}
$$


To determine the population affected by HEl's on a state and macro regional level, the population of the micro-regions were added every time the micro-region had at least one $\mathrm{HEl}$, despite of the CPC grade and the presence of additional institutions.

Also, to understand the impact of $2011 \mathrm{HEl}$ 's graduates, the total number of active engineers information was included on the macro-regional level, represented by the total of enabled engineers according to CONFEA in 2016. The objective is to visualize the tendency of growth on each region and to understand the impacts over a 5-year period.

To finalize the statistical and data gathering, a compilation of each micro-region by state and by macro regions (North, Northeast, Central-West, Southeast and South) was conducted to compare with GDP findings from previous studies.

\section{Results and discussion}

The first part of the analysis of the study was conducted using the HEl's and their location. The objective is to understand what is the state's population impacted by HEl's presence in their micro-region. This analysis also shows the distribution of population between the several states of the country and will allow for other findings. Results are showed in Figure 2 in which a population affected by a HEl's is considered when a micro-region has at least one HEl (despite of the CPC index).

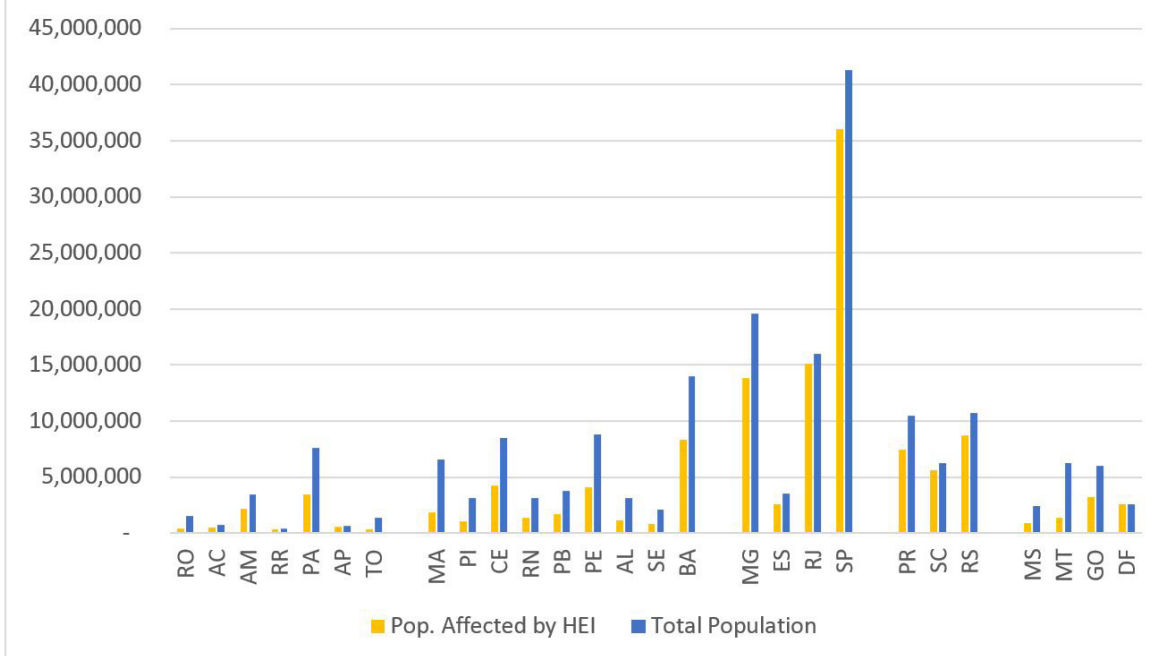

Figure 2. Total Population and Population with HEl access by state. Source: (IBGE, 2012; INEP, 2015). Organization by the authors.

Figure 2 shows a concentration of population in the Southeast macro region. The state of São Paulo (SP) alone has a little over 41 million inhabitants $-21.27 \%$ of the country's population. This gives it a great advantage on the development set as it will yield better results. Not only from taxes and economic movement, but also intellectual capital and resources from federal funding. The complete North region has close to 16 million, less than half of São Paulo with an area 15 times bigger $\left(3,853,676 \mathrm{~km}^{2}\right.$ versus 248,209 $\left.\mathrm{km}^{2}\right)$. Just the population distribution already poses a great challenge for equal country development. The concentration of population also encourages regional perspectives, as seen in Quandt (1997), Costa (2010) and Oliveira (2011), with the national standards greatly affected by the Southeast region because of its population concentration.

The second part of the analysis of the study is showed in Figure 3. The analysis is conducted from a different approach, in which the results were sorted not by population but by micro-regions (again this analysis also does not take into consideration the CPC index or quantity of HEl's). The number of micro-regions with HEl's can show the potential of equal growth in each state. It will also present a scenario in which only 6 of 27 states (this includes the DF is, which is the nation's capital and a "city and state" at the same time) have a coverage over 50\%. The concentration of high quality HEl's in the South and Southeast regions was already displayed in Figure 1, but this new analysis also displays that the geographical distribution in these regions is far better than other regions such as the North and Northeast. 


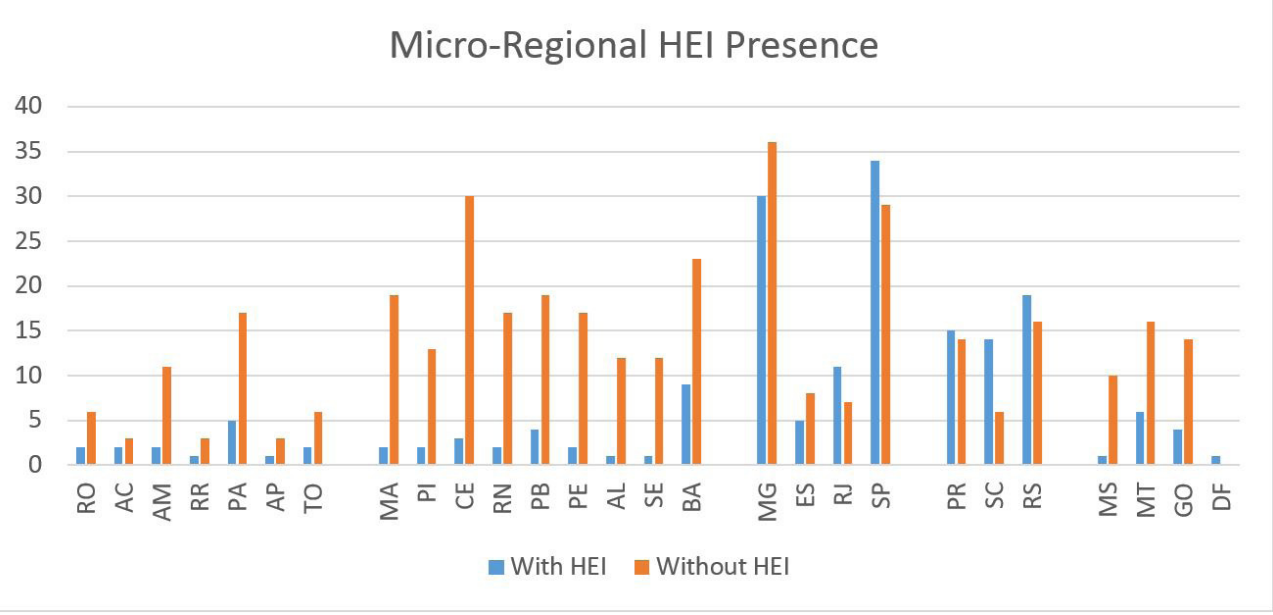

Figure 3. Micro-regions with and without HEl's by state. Source: (IBGE, 2012; INEP, 2015). Organization by the authors.

Figure 3 also indicates a great disparity in the developing of regions. Even if there is not a structural shortage of engineers, as pointed out by lins et al. (2014), the micro-regional scenario presents an uneven distribution of HEl's. The only macro regions with above 50\% coverage are Southeast and South, the best two regions in GDP participation. All other regions fall greatly behind with the Northeast with as low as 16\% of micro-regions with HEl's. From the 16 micro-regions that do have HEl's 9 of them are state capitals leaving only 7 others for the entire macro region. This scenario indicates a great challenge to implement the advantages of university products and their benefits as described by Lendel (2010) and properly developing regions as proposed by Oliveira (2011) and Quandt (1997). Even if the micro-region import engineers from other areas it will not see the long-term benefits of having a HEl and the spillovers as described by Drucker (2016).

Even though it varies from each state, the micro-regional tendency of population aggregation is seen in all cases as represented by the number of people affected by HEl's when compared to their spread over the micro-regions. In all states the percentage of regions is lower than the percentage of the population attended by the HEl. This shows that HEl's are typically placed in dense populated areas, which can justify the costs associated and the demand for infrastructure.

The effect seen is particularly valid in the micro-regions that hold the capital for each state. The general numbers of capital micro-regions will be higher than the rest of the micro-regions in each state for two fundamental points: 1) higher population and opportunities, included on a larger industrial and service set and 2) the presence of a stronger governmental structure, not only in terms of administration but also federal and state HEl's. The analysis indicates that the capital's micro-region influences directly the results because of their population and importance in the regional scene. This explains why with a lesser percentage in distribution of HEl's the population affected by them are greater in percentage.

Another information that was determined in this study is the total graduates per micro-region compared to the population. Since the difference in population between regions is severe (as seen in Figure 2), this study used the presence of graduates by 10,000 people. A separation was made not only by graduates but also by graduates from high performance HEl's (CPC4 and CPC5). An average is calculated and displayed against the number of enabled engineers from 2016. The numbers are shown in Table 1.

From Table 1 a hypothesis is made where the current situation will not be reversed as the even spread of HEl's and Engineers is not met and the regions with the most development are the regions that graduate more engineers per 10,000 inhabitants. Table 1 also shows that the regions without high outputs in graduating engineers have not been able to constantly and steady import them from other regions and as such the regions are kept from the benefits of their presence and capabilities, thus being unable to leverage their GDP participation. It is also possible to notice that the North region is the only in which a state (AC, RR and AP) has not a single High Quality Engineering HEl.

To finalize this portion of the analysis of the presence and participation in the global country population, the general results for each macro region is displayed on Table 2. This final step shows that the good distribution of HEl's is as important as the population distribution for GDP results. This is very clear on the South macro 
T. Graduation and Total Engineers results.

\begin{tabular}{|c|c|c|c|c|c|}
\hline Macro Region & State & Graduates (2011) & $\begin{array}{l}\text { CPC4 and CPC5 } \\
\text { Graduates (2011) }\end{array}$ & $\begin{array}{l}\text { State Graduates } \\
\text { (2011) }\end{array}$ & $\begin{array}{c}\text { Total Enabled } \\
\text { Engineers (2016) }\end{array}$ \\
\hline \multirow{4}{*}{ Central-West } & MS & 1.164 & 0.355 & \multirow{4}{*}{2.233} & \multirow{4}{*}{60,585} \\
\hline & MT & 3.707 & 1.474 & & \\
\hline & GO & 1.344 & 0.205 & & \\
\hline & DF & 1.743 & 1.393 & & \\
\hline \multirow{9}{*}{ Northeast } & MA & 0.345 & 0.047 & \multirow{9}{*}{1.608} & \multirow{9}{*}{110,509} \\
\hline & $\mathrm{Pl}$ & 0.555 & 0.125 & & \\
\hline & $\mathrm{CE}$ & 0.814 & 0.336 & & \\
\hline & RN & 1.515 & 0.606 & & \\
\hline & PB & 1.306 & 0.558 & & \\
\hline & $\mathrm{PE}$ & 1.131 & 0.013 & & \\
\hline & AL & 1.035 & 0.208 & & \\
\hline & SE & 1.731 & 0.575 & & \\
\hline & $\mathrm{BA}$ & 1.380 & 0.153 & & \\
\hline \multirow{7}{*}{ North } & RO & 0.762 & 0.262 & \multirow{7}{*}{1.351} & \multirow{7}{*}{38,345} \\
\hline & $A C$ & 2.863 & 0 & & \\
\hline & $\mathrm{AM}$ & 1.860 & 0.092 & & \\
\hline & $\mathrm{RR}$ & 0.549 & 0 & & \\
\hline & PA & 1.156 & 0.021 & & \\
\hline & AP & 0.956 & 0 & & \\
\hline & TO & 1.496 & 0.860 & & \\
\hline \multirow{4}{*}{ Southeast } & MG & 3.774 & 0.960 & \multirow{4}{*}{3.474} & \multirow{4}{*}{470,279} \\
\hline & ES & 2.384 & 1.047 & & \\
\hline & RJ & 3.438 & 0.924 & & \\
\hline & SP & 3.439 & 0.749 & & \\
\hline \multirow{3}{*}{ South } & PR & 3.246 & 1.065 & \multirow{3}{*}{3.225} & \multirow{3}{*}{136,372} \\
\hline & SC & 3.707 & 1.474 & & \\
\hline & RS & 2.922 & 1.657 & & \\
\hline
\end{tabular}

Source: (CONFEA, 2016; INEP, 2015), Organization by the authors.

Table 2. Macro Regions results.

\begin{tabular}{cccccc}
\hline Macro Region & \% Population & \% Enabled Engineers & $\begin{array}{c}\text { \% Population } \\
\text { with HEl }\end{array}$ & $\begin{array}{c}\text { \% Micro-regions } \\
\text { with HEl's }\end{array}$ & $\begin{array}{c}\text { \% of GDP } \\
\text { participation }\end{array}$ \\
\hline Central-West & 8.90 & 7.42 & 47 & 23 & 9.60 \\
Northeast & 27.37 & 13.54 & 47 & 14 & 13.40 \\
North & 8.18 & 4.70 & 49 & 23 & 5.40 \\
Southeast & 41.43 & 57.63 & 84 & 50 & 65.20 \\
South & 14.12 & 16.71 & 79 & 51 & 16.20 \\
\hline
\end{tabular}

Source: (CONFEA, 2016; IBGE, 2012; INEP, 2015), Organization by authors.

region, that with close to half the population of the Northeast (14.12\% against $27.37 \%)$ can still present a better GDP participation (16.2\% against 13.4\%). It is also clear from the data that the percentage of North and Central-West population limits their capacity to equalize the GDP participation, pointing to a regional shortage of policies to equally develop the country.

The scenario present a challenging set, needing policies and curriculum adapted to regional needs as described by Lansu et al (2013) and Devine-Wright et al. (2001) as the regions in which more development is needed are not only the regions where there is less access to HEl's but also were there is less population affected by the HEl's spillovers (Drucker, 2016; Lendel, 2010) and less HRST personal to enforce a positive regional economy (Oliveira, 2011; Quandt, 1997).

As discussed before, capital micro-regions present a strong influence in the state comparisons and as such, most comparisons from this point on will not only account for absolute numbers, but will also compare the results of micro-regions with and without HEl's. Removing the capital's micro-region absolute was necessary to better understand the spillover in regions with less population. 
The final analysis is made by comparing the micro-regions in each state and the HDI_Education and HDI_Income index compared to the state value to determine how they are contributing to the local development. For this part, as mentioned before, an absolute analysis as well as a comparative analysis without the capital will be made. The influence of the capital can be clearly seen on the analysis of the data. Several states (MS, $\mathrm{AL}, \mathrm{SE}, \mathrm{AC}, \mathrm{RR}, \mathrm{AP}$ ) shows that only the capital micro-region could get better results. Also, it is clear the impact of HEl's in a possible outcome of HDI_Education and HDI_Income is not the single factor and a cause-effect situation can't be established.

The first part of this analysis is demonstrated in Table 3. The DF results are not entered as it is the Nation's Capital and a city and state at the same time. We divided the analysis creating 4 different categories that are shown in the Table 3:

- MRW+: The number of micro-regions with at least one HEl which has a better HDI index than the state value

- MRW-: The number of micro-regions with at least one HEl which has a worse HDI index than the state value

- MRN+: The number of micro-regions without HEl which has a better HDI index than the state value

- MRN-: The number of micro-regions without HEl which has a worse HDI index than the state value

Another information from Table 3 is the number of micro-regions without HEl's that can achieve better HDl_Education and HDI_Income. In the entire country, only 22 (in a total of 377) - or 5.8\% - were able to achieve a better HDI_Education than the state reference and only 14 - or 3.7\% - where able to get a better HDI_Income.

When the capital micro-region is removed from the analysis, it is possible to notice that the majority of the regions with HEl's will have a better HDI_Education and HDI_Income that the regions without HEl's. The effect of the quantity of graduates and quality is also pertinent. This proves the hypothesis and confirms the results

Table 3. Micro-Regional HDl_Education and HDI_lncome results.

\begin{tabular}{|c|c|c|c|c|c|c|c|c|c|}
\hline \multirow{2}{*}{ Macro Region } & \multirow{2}{*}{ State } & \multicolumn{4}{|c|}{ HDI_EDUCATION } & \multicolumn{4}{|c|}{ HDI_INCOME } \\
\hline & & MRW+ & MRW- & $\mathrm{MRN}+$ & MRN- & MRW+ & MRW- & MRN+ & MRN- \\
\hline \multirow{4}{*}{ Central-West } & MS & 1 & 0 & 1 & 9 & 1 & 0 & 1 & 9 \\
\hline & MT & 3 & 3 & 3 & 13 & 3 & 3 & 3 & 13 \\
\hline & GO & 2 & 2 & 0 & 14 & 3 & 1 & 0 & 14 \\
\hline & $\mathrm{DF}$ & - & - & - & - & - & - & - & - \\
\hline \multirow{9}{*}{ Northeast } & MA & 2 & 0 & 0 & 19 & 2 & 0 & 2 & 17 \\
\hline & $\mathrm{Pl}$ & 1 & 1 & 1 & 12 & 1 & 1 & 0 & 14 \\
\hline & CE & 2 & 1 & 0 & 32 & 1 & 2 & 0 & 30 \\
\hline & RN & 2 & 0 & 0 & 17 & 2 & 0 & 0 & 17 \\
\hline & PB & 3 & 1 & 0 & 19 & 2 & 2 & 0 & 19 \\
\hline & PE & 1 & 1 & 3 & 14 & 1 & 1 & 1 & 16 \\
\hline & $\mathrm{AL}$ & 1 & 0 & 0 & 12 & 1 & 0 & 0 & 12 \\
\hline & SE & 1 & 0 & 0 & 12 & 1 & 0 & 0 & 12 \\
\hline & BA & 4 & 5 & 1 & 22 & 3 & 6 & 0 & 23 \\
\hline \multirow{7}{*}{ North } & RO & 1 & 1 & 1 & 5 & 1 & 1 & 1 & 5 \\
\hline & $A C$ & 1 & 0 & 0 & 4 & 1 & 0 & 0 & 4 \\
\hline & AM & 1 & 1 & 0 & 11 & 1 & 1 & 0 & 11 \\
\hline & RR & 1 & 0 & 0 & 3 & 1 & 0 & 0 & 3 \\
\hline & PA & 3 & 2 & 2 & 15 & 3 & 2 & 2 & 15 \\
\hline & AP & 1 & 0 & 0 & 3 & 1 & 0 & 0 & 3 \\
\hline & TO & 2 & 0 & 2 & 4 & 2 & 0 & 2 & 4 \\
\hline \multirow{4}{*}{ Southeast } & $\mathrm{MG}$ & 19 & 11 & 4 & 32 & 8 & 22 & 1 & 35 \\
\hline & ES & 1 & 4 & 0 & 8 & 1 & 4 & 0 & 8 \\
\hline & RJ & 3 & 8 & 0 & 7 & 2 & 9 & 0 & 7 \\
\hline & SP & 19 & 15 & 0 & 29 & 4 & 30 & 0 & 29 \\
\hline \multirow{3}{*}{ South } & PR & 7 & 8 & 1 & 23 & 3 & 12 & 0 & 24 \\
\hline & $\mathrm{SC}$ & 6 & 8 & 0 & 6 & 4 & 10 & 0 & 6 \\
\hline & RS & 10 & 9 & 3 & 13 & 4 & 15 & 1 & 15 \\
\hline
\end{tabular}

Source: (INEP, 2015; PNUD et al., 2013), Organization by the authors. 
from other researches that the presence of HEl's on the micro-region will yield benefits regardless of products and production capacity.

The states of Minas Gerais (MG), São Paulo (SP), Paraná (PR) and Rio Grande do Sul (RS) shows an interesting concentration of income in the micro-regions with HEl's as the reduction between HDI_Education to HDI_Income is significant. In both cases the capitals HDI_Income was more significant than the HDl_Education and because of the population on those micro-regions they reflected "negatively" on the remaining micro-regions. The state of Espírito Santo (ES) shows clearly the distortion made by the capital. Even though in the best macro region - Southeast - only the capital has positive HDI_Education and HDI_Income indicators. The impact is significant as close to $45 \%$ of the population resides in the capital micro-region of the ES state.

On the least developed macro regions of the country the presence of a HEl is a solid indication of better HDI_Education and HDI_Income. Central-West, North and Northeast regions display that the majority of the micro-regions with HEl's were able to reach better HDI standards and that the lack of presence of HEl's would yield worse comparative indexes in the majority of cases.

On the qualitative analysis, it is possible to determine that all regions with HEl's even with a negative comparison results shows an increase in HDI indexes over the micro-regions without HEl's. Even though the calculated indexes are still lower than the state reference, used in this study as a reference, they are considerably closer to the state reference, which would enforce the idea of the spillover region and regional importance as described by Drucker (2016) and Lendel (2010) and the impact of the capital's micro-region as described before. The worst comparative results on all regions, in all cases, were from micro-regions with low population and no HEl.

\section{Conclusions}

Brazil has Engineering HEl's in 181 of a total of 558 micro-regions, a 32\% presence. However, when looking at the population that benefits from the presence of the HEl's on their micro-region the percentage raises significantly to $66 \%$ and close to 130 million have access to the benefits. The presence of HEl's in micro-regions is stronger on the most developed parts of the country, with the Southeast region having as much as $84 \%$ of its population affected by HEl's and their presence in 50\% of the micro-regions. This again shows the distance from other less developed regions and the great difficulty to equally develop the country.

As previous studies demonstrated, the percentage of high performance engineers was directly correlated to GDP participation. This study can now conclude that the number of enabled engineers is equally important when making such comparison as showed in Table 2. From this study is also possible to conclude that the regions with the most need for development have today very fewer graduates per 10,000 inhabitants, showing that this scenario will not change in the near future if actions by the key stakeholders are not taken to balance these numbers. Again, the South and Southeast region are leading with over 3 graduates per 10,000 inhabitants and regions such as the North and Northeast have a value close to half of that.

Another conclusion is that the least developed regions are the ones "importing" the workforce from the other more developed states. Even if this somehow balances the presence of engineers according to the population, the lack of HEl's on that regions prevent the natural benefits and spillovers to be observed. General education, local connection and development can't be met if the key stakeholders are not completely integrated and compromised on that project. This can be a starting point for policies to better use the $62 \%$ graduated engineers that, according to Maciente \& Araújo (2011), are not in their typical professions.

This paper adds to the current research database, adding a micro-regional assessment as well as tendency and distribution analysis not only of the HEl's but the population affected by them. A method to better distribute the HEl's and population needs to be studied so the country can equally develop its regions. As shown by the comparison between 2011 graduates and the most recent enabled engineers, several policies need to be implemented to enhance the presence of engineers on the macro-regions with the highest need for development.

Since the presence of HEl's and the population of the micro-regions are directly connected, a possible future study would be the assessment of case studies of implementations of HEl's and what would be the impact over time in which HEl's in terms of increased population, and the provision of the necessary products and beneficial spillovers over the micro-region that would be represented by better HDI indexes. As other possible future research the authors recommend the geographical study of the data matrix, the mathematical correlation study of the raw data and a similar study to the presented here but with a focus on the HRST industry and technical clusters as a development tool instead of education. 


\section{References}

Andrade, E. C. (2011). Rankings em educação: tipos, problemas, informações e mudanças. Estudos Econômicos, 41(2), 323-343. https:// doi.org/10.1590/S0101-41612011000200005.

Barbosa, M. L. 0., \& Santos, C. T. (2011). A permeabilidade social das carreiras do ensino superior. Caderno CRH, 24(63), 535-554. http://dx.doi.org/10.1590/S0103-49792011000300006.

Conselho Federal de Engenharia e Agronomia - CONFEA. (2016). Profissionais - engenheiros ativos por região. Brasília: CONFEA. Retrieved in 11 October 2016, from http://www.confea.org.br/cgi/cgilua.exe/sys/start.htm?tpl=home

Costa, E. J. M. (2010). Arranjos produtivos locais, políticas públicas e desenvolvimento regional. Brasília: Mais Gráfica Editora.

Devine-Wright, P., Fleming, P. D., \& Chadwick, H. (2001). Role of social capital in advancing regional sustainable development. Impact Assessment and Project Appraisal, 19(2), 161-167. http://dx.doi.org/10.3152/147154601781767096.

Drucker, J. (2016). Reconsidering the regional economic development impacts of higher education institutions in the United States. Regional Studies, 50(7), 1185-1202. http://dx.doi.org/10.1080/00343404.2014.986083.

Instituto Brasileiro de Geografia e Estatística - IBGE. (2012). Contas Regionais. Rio de Janeiro: 1BGE. Retrieved in 24 November 2015, from http://www.ibge.gov.br/home/estatistica/economia/contasregionais/2012/default_xls_1995_2012.shtm

Instituto Brasileiro de Geografia e Estatística - IBGE. (2014). Contas Nacionais Trimestrais - 2014. Rio de Janeiro: IBGE. Retrieved 24 May 2015, from ftp://ftp.ibge.gov.br/Contas_Nacionais/Contas_Nacionais_Trimestrais/Fasciculo_Indicadores_lBGE/pib-volval_201404caderno.pdf

Instituto Nacional de Estudos e Pesquisas Educacionais Anísio Teixeira - INEP. (2011). Relatório Síntese 2011. Brasília: INEP. Retrieved in 26 November 2015, from http://portal.inep.gov.br/web/guest/enade/relatorio-sintese-2011

Instituto Nacional de Estudos e Pesquisas Educacionais Anísio Teixeira - INEP. (2015). Enade - Inep. Brasília: INEP. Retrieved in 30 November 2015, from http://portal.inep.gov.br/enade

Instituto Nacional de Estudos e Pesquisas Educacionais Anísio Teixeira - INEP. (2016). Notas Técnicas - Inep. Brasília: INEP. Retrieved in 9 October 2016, from http://portal.inep.gov.br/educacao-superior/indicadores/notas-tecnicas

Kakiuthi, A., Matsuyama, R. T, Pimentel, F. P., \& Moraes, T. M. M. (2014). Improving science education through new perspectives. In Proceedings of the 2014 IEEE Global Humanitarian Technology Conference (GHTC). San Jose, CA, USA. https://doi.org/10.1109/ GHTC.2014.6970269.

Lansu, A., Boon, J., Sloep, P. B., \& van Dam-Mieras, R. (2013). Changing professional demands in sustainable regional development: a curriculum design process to meet transboundary competence. Journal of Cleaner Production, 49, 123-133. http://dx.doi. org/10.1016/j.jclepro.2012.10.019.

Lendel, 1. (2010). The impact of research universities on regional economies: the concept of universitiy products. Economic Development Quarterly, 24(3), 210-230. http://dx.doi.org/10.1177/0891242410366561.

Lins, L. M., Salerno, M. S., Araújo, B. C., Gomes, L. A. V., Nascimento, P. A. M. M., \& Toledo, D. (2014). Escassez de Engenheiros no Brasil? Novos Estudos, 98(98), 43-67. http://dx.doi.org/10.1590/S0101-33002014000100004.

Lozano, R., Ceulemans, K., Alonso-Almeida, M., Huisingh, D., Lozano, F. J., \& Waas, T., Lambrechtsh, W., \& Lukman, R., \& Hugé, J. (2014). A review of commitment and implementation of sustainable development in higher education: results from a worldwide survey. Journal of Cleaner Production, 108, Part A, 1-18. https://doi.org/10.1016/j.jclepro.2014.09.048.

Maciente, A. N., \& Araújo, T. C. (2011). A demanda por engenheiros e profissionais afins no mercado de trabalho atual. Radar, 12, 43-54.

Nascimento, P. A. M. M. (2011). Há escassez generalizada de profissionais de carreiras técnico-científicas no Brasil? Uma análise a partir de dados do CAGED. Mercado de Trabalho, 49, 19-28.

Nascimento, P., Maciente, A., Gusso, D., Araújo, T. C., \& Silva, A. P. T. (2010). Escassez de engenheiros: realmente um risco. Radar, 6, 3-8.

Oliveira, G. B. (2011). Regiões inteligentes como estratégia de desenvolvimento local. Revista Orbis Latina, 1(1), 35-39.

Pederneiras, M. M. M., Lopes, J. E. G., Ribeiro Filho, J. F., \& Feitosa, M. G. G. (2011). Exame Nacional de Desempenho dos Estudantes na visão de líderes formais. Ensaio: Avaliação e Políticas Públicas em Educação, 19(71), 381-400.

Programa das Nações Unidas para o Desenvolvimento - PNUD, Instituto de Pesquisa Econômica Aplicada - IPEA, \& Fundação João Pinheiro. (2013). Atlas do Desenvolvimento Humano no Brasil. Retrieved in 3 January 2016, from http://www.atlasbrasil.org.br/2013/

Quandt, C. O. (1997). Inovação, competitivdade e desenvolvimento Regional: os desafios da reestruturação prodituvia do Estado. Revista Paranaense de Desenvolvimento, 91, 9-32.

Salerno, M. S., Lins, L. M., Araújo, B. C., Gomes, L. A. V., Toledo, D., \& Nascimento, P. A. M. M. (2014). Uma proposta de sistematização do debate sobre falta de engenheiros no Brasil. Brasília: Ipea. Retrieved in 23 March 2015, from http://repositorio.ipea.gov.br/ handle/11058/3142

Stephens, J. C., Hernandez, M. E., Román, M., Graham, A. C., \& Scholz, R. W. (2008). Higher education as a change agent for sustainability in different cultures and contexts. International Journal of Sustainability in Higher Education, 9(3), 317-338. http:// dx.doi.org/10.1108/14676370810885916.

Zilahy, G., \& Huisingh, D. (2009). The roles of academia in regional sustainability initiatives. Journal of Cleaner Production, 17(12), 1057-1066. http://dx.doi.org/10.1016/j.jclepro.2009.03.018. 